\begin{tabular}{|cc|}
\hline ALKENES & ARENES \\
1,3-BUTADIENE & BENZENE \\
GASOLINE & EXHAUST \\
ANALYSIS & EXPOSURE \\
MOTORIST & CHILDREN \\
\hline
\end{tabular}

Open access accepted manuscript version of Chemosphere 25 (1992) 691-696

\title{
Volatile hazardous hydrocarbons in a Scandinavian urban road tunnel
}

\author{
Gunnar Barrefors and Göran Petersson \\ Department of Chemical Environmental Science, Chalmers University of Technology, \\ S-41296 Göteborg (Sweden)
}

The results imply severe exposure to people in vehicles using road tunnels and influenced extensive plans for long road tunnels in Stockholm and Göteborg. 


\title{
VOLATILE HAZARDOUS HYDROCARBONS IN A SCANDINAVIAN URBAN ROAD TUNNEL
}

\author{
Gunnar Barrefors and Göran Petersson \\ Department of Chemical Environmental Science \\ Chalmers University of Technology \\ 41296 Göteborg, Sweden
}

\begin{abstract}
Vehicle-emitted hydrocarbons were assessed in the major Tingstad Tunnel in Göteborg, Sweden. Samples were taken on adsorbent cartridges and analyzed by gas chromatography after thermal desorption. Although the tunnel is only $454 \mathrm{~m}$ long, the concentration levels were found to be approximately five times higher than inside commuter cars on roads with similar traffic.

Representative proportions of non-methane hydrocarbons were $14 \%$ for alkenes, $32 \%$ for alkanes and as much as $49 \%$ for arenes. Benzene and ethene, representing particular health hazards constituted $\sim 7 \%$ each. Characteristic concentration ratios are given for sixteen alkenes and alkadienes.

Health hazards for vulnerable motorists and implications for existing and planned road tunnels are discussed.
\end{abstract}

\section{INTRODUCTION}

Increased traffic and improved techniques for the construction of road tunnels has led to extensive plans for new road tunnels in Scandinavia and Europe. A major concern with road tunnels is the potential health hazards attributable to the strongly elevated levels of air pollutants. Specific inorganic and organic pollutants have been studied for European tunnels in Belgium (Vanderstraeten et al., 1991) and Germany (Danecker et al., 1990).

A recent review of tunnel studies in the U.S. (Pierson et al., 1990) demonstrates that concentrations of volatile hydrocarbons are much higher than predicted by various theoretical models. There is also increasing concern about health hazards from hydrocarbons such as alkenes (Törnqvist and Ehrenberg, 1990) and benzene (Yardley-Jones et al., 1991). The purpose of our study is to characterize the occurrence of a wide range of volatile hydrocarbons in a major Scandinavian tunnel. 


\section{EXPERIMENTAL}

\section{The Tingstad Tunnel}

Göteborg, with its population of half a million people, is located on the Swedish west coast, northwest and southeast of the mouth of the Göta Älv river. The major road-traffic link between the two parts of the city is the Tingstad Tunnel, which is also part of the E6 highway through Göteborg.

The tunnel consists of two $4.5 \times 12.5 \mathrm{~m}$ one-way tubes with three lanes in each. It is $454 \mathrm{~m}$ long, with a maximum slope of $40 \%$ and a lowest lane level of $14 \mathrm{~m}$ below the water surface. The average diurnal traffic flow through one tube exceeds 2000 vehicles per hour. The maximum speed through the tunnel is $70 \mathrm{~km} / \mathrm{h}$, as stated on signboards. Normally, the tubes are ventilated only by the air flow $(\sim 5 \mathrm{~m} / \mathrm{s})$ caused by the vehicles. Additional mechanical ventilation is switched on automatically by high $\mathrm{CO}$ levels during traffic congestion.

By the time of the study, an estimated portion of almost $50 \%$ of the private cars passing through the tunnel were equipped with three-way catalytic converters and canisters. The portion of heavyduty vehicles through the tunnel was observed to be $\sim 10 \%$ on all sampling occasions.

\section{Sampling and analysis}

Samples were taken on adsorbent cartridges and analyzed in the laboratory using thermal desorption and gas chromatography, essentially as descibed in a recent methodological report (Löfgren et al., 1991a).

The winter samples were taken $\sim 20 \mathrm{~m}$ from the exit of the tunnel tube with south-bound traffic, and the summer samples halfway through the same tube. The sampling cartridges and air pumps were placed on the narrow catwalk, less than $1 \mathrm{~m}$ from the nearest vehicles. The triple-layer adsorbent cartridges contained Tenax TA, Carbotrap and Carbosieve S-III. On each occasion, 4-6 parallel samples were taken to check potential analytical errors caused by the reactive atmosphere in the tunnel. Some samples were taken with Tenax as the only adsorbent. The sampling volumes varied in the range of $200-1000 \mathrm{ml}$.

In the laboratory, the hydrocarbons were thermally desorbed at $235^{\circ} \mathrm{C}$ into the cold trap of the gas chromatograph. The temperature-programmed separations were performed on a $50 \mathrm{~m} \times 0.32$ mm i.d. PLOT column, with $\mathrm{Al}_{2} \mathrm{O}_{3} / \mathrm{KCl}$ as the stationary phase. The same FID response (1.00) was applied for all hydrocarbons except benzene (1.08), methylbenzene (1.04) and dimethylbenzenes (1.02).

The whole range of $\mathrm{C}_{2}-\mathrm{C}_{8}$ hydrocarbons was adequately determined on the analytical system. The $\mathrm{C}_{9}-\mathrm{C}_{10}$ arenes were taken as their recently reported proportion relative to $\mathrm{C}_{8}$ arenes in road vehicle emissions (Löfgren et al., 1991b).

\section{RESULTS}

\section{Concentration levels}

In Table 1, concentrations of ethene, propene, benzene and methylbenzene (toluene) are given for five sampling occasions, selected to represent different circumstances of interest.

The high concentrations of February 19 are explained by traffic congestion and partly by 
Table 1. Concentrations $\left(\mu \mathrm{g} / \mathrm{m}^{3}\right)$ of hydrocarbons in the air of the Tingstad Tunnel.

\begin{tabular}{lccccc}
\hline Date & $02 / 19-92$ & $02 / 10-92$ & $01 / 15-92$ & $06 / 27-91^{\mathrm{a}}$ & $06 / 27-91^{\mathrm{a}, \mathrm{b}}$ \\
Time & $08.10-08.40$ & $14.45-15.25$ & $07.30-08.05$ & $13.45-14.35$ & $20.30-21.00$ \\
Ambient temp. & $-4^{\circ} \mathrm{C}$ & $3{ }^{\circ} \mathrm{C}$ & $60^{\circ} \mathrm{C}$ & $18^{\circ} \mathrm{C}$ & $16^{\circ} \mathrm{C}$ \\
Speed interval $(\mathrm{km} / \mathrm{h})$ & $0-70$ & $60-80$ & $60-80$ & $60-80$ & $0-40$ \\
Vehicles $(\mathrm{per} \mathrm{h})$ & 3200 & 3200 & 4700 & 3300 & 3200 \\
\hline $\mathrm{CH}_{\mathrm{x}}\left(\mathrm{C}_{2}-\mathrm{C}_{10}\right)$ & 4110 & 1530 & 3590 & 830 & 6690 \\
ethene & 279 & 113 & 295 & 51 & 405 \\
propene & 100 & 48 & 112 & 13 & 160 \\
benzene & 301 & 104 & 237 & 61 & 450 \\
methylbenzene & 604 & 214 & 460 & 124 & 980 \\
& & & & & \\
\hline
\end{tabular}

a) Samples taken in the middle of the tunnel.

b) Slow traffic in both directions in the tunnel tube.

increased emissions at low ambient temperature (Stump et al., 1989). The high levels of January 15 are associated with the peak flow of traffic in the morning. The moderate levels of Febuary 10 and June 27 correspond to a favourable traffic flow during winter and summer days. The extremely high concentrations of the evening of June 27 were due to temporary traffic in both directions in the tunnel tube. An even and not too slow one-way flow of traffic is evidently essential for a proper ventilation of the tunnel.

The morning rush hour levels are approximately five times higher than those inside commuter cars on a highway near to Göteborg (Löfgren et al., 1991b). They are of the same order of magnitude as those reported for the Lincoln Tunnel in New York (Lonneman et al., 1986).

\section{Composition of hydrocarbons}

In Table 2, percent proportions are given for total and individual alkenes, alkanes and arenes. The composition of hydrocarbons was remarkably similar on the five reported occasions representing different ambient temperatures, seasons, times of day, and traffic flows. The two sampling occasions from the critical morning rush hours exhibit almost identical percent ratios. The observed composition ranges were $12-16 \%$ for alkenes, $30-34 \%$ for alkanes and $47-51 \%$ for arenes. This is very different from the United States where corresponding proportions are roughly $20 \%$, $40 \%$ and $30 \%$ (Sheff et al., 1989). The high proportion of arenes is due primarily to the high content of reformate in petrol from Swedish and many other European refineries. A similar high proportion of arenes was recently reported for highway and urban air pollution in Göteborg (Löfgren and Petersson, 1992). Lowered limits for the vapour pressure of Swedish petrol appear to have lowered the proportions of butanes since that study.

A wide range of alkenes, including alkadienes, are reported because of the increasing concern about their contribution to photooxidants and their impact on health. The approximate proportions 10:4:1 were observed for the combustion products ethene, propene and butadiene (carcinogenic) in accordance with results for urban air (Löfgren and Petersson, 1992). The high proportion of heavyduty diesel vehicles $(\sim 10 \%)$ tends to increase the percentages of ethene and propene in the 
Table 2. Proportions (\%) of non-methane volatile hydrocarbons in the air of the Tingstad tunnel.

\begin{tabular}{|c|c|c|c|c|c|}
\hline Date & 03/11-92 & $02 / 19-92$ & $02 / 10-92$ & $06 / 27-91$ & $06 / 27-91$ \\
\hline Time & $07.50-0820$ & $08.10-08.40$ & $14.45-15.25$ & $13.45-14.35$ & $20.30-21.00$ \\
\hline Ambient temp. & $5^{\circ} \mathrm{C}$ & $-4^{\circ} \mathrm{C}$ & $3^{\circ} \mathrm{C}$ & $18^{\circ} \mathrm{C}$ & $16^{\circ} \mathrm{C}$ \\
\hline Speed interval $(\mathrm{km} / \mathrm{h})$ & $40-80$ & $0-70$ & $60-80$ & $60-80$ & $0-40$ \\
\hline Vehicles (per h) & 4100 & 3200 & 3200 & 3300 & 3200 \\
\hline Conc of $\mathrm{CH}_{\mathrm{x}}\left(\mu \mathrm{g} / \mathrm{m}^{3}\right)$ & 1940 & 4110 & 1530 & 830 & 6690 \\
\hline Alkenes $\left(C_{2} \cdot C_{6}\right)$ & 13.2 & 13.7 & 15.3 & 12.8 & 12.5 \\
\hline ethene & 6.5 & 6.8 & 7.4 & 6.2 & 6.1 \\
\hline propene & 2.9 & 2.4 & 3.1 & 1.6 & 2.4 \\
\hline propadiene & 0.24 & 0.20 & 0.26 & 0.14 & 0.12 \\
\hline trans-2-butene & 0.24 & 0.27 & 0.28 & 0.30 & 0.28 \\
\hline 1-butene & 0.41 & 0.56 & 0.41 & 0.33 & 0.40 \\
\hline methylpropene & 0.78 & 0.95 & 1.01 & 0.88 & 0.75 \\
\hline cis-2-butene & 0.16 & 0.20 & 0.20 & 0.25 & 0.19 \\
\hline butadiene & 0.68 & 0.63 & 0.65 & 0.40 & 0.33 \\
\hline cyclopentene & 0.05 & 0.06 & 0.06 & 0.08 & 0.06 \\
\hline 3-methyl-1-butene & 0.06 & 0.07 & 0.08 & 0.11 & 0.08 \\
\hline trans-2-pentene & 0.16 & 0.17 & 0.20 & 0.31 & 0.25 \\
\hline 2-methyl-2-butene & 0.25 & 0.25 & 0.31 & 0.41 & 0.30 \\
\hline 1-pentene & 0.15 & 0.17 & 0.16 & 0.22 & 0.18 \\
\hline 2-methyl-1-butene & 0.17 & 0.21 & 0.27 & 0.33 & 0.24 \\
\hline cis-2-pentene & 0.07 & 0.09 & 0.10 & 0.17 & 0.14 \\
\hline 1-hexene & 0.07 & 0.09 & 0.09 & 0.10 & 0.08 \\
\hline Alkanes $\left(C_{2}-C_{9}\right)$ & 31.3 & 30.5 & 31.0 & 33.4 & 33.8 \\
\hline methylpropane & 2.2 & 2.4 & 2.2 & 1.5 & 2.4 \\
\hline butane & 4.2 & 4.2 & 4.2 & 3.5 & 4.6 \\
\hline methylbutane & 7.3 & 6.2 & 6.3 & 7.3 & 6.7 \\
\hline pentane & 3.3 & 2.8 & 3.1 & 3.3 & 3.1 \\
\hline methylcyclopentane & 1.6 & 1.6 & 1.8 & 2.0 & 1.9 \\
\hline 2-methylpentane & 2.7 & 2.5 & 2.5 & 3.1 & 3.0 \\
\hline 3-methylpentane & 1.8 & 2.1 & 2.0 & 2.4 & 2.2 \\
\hline hexane & 1.5 & 1.8 & 1.6 & 1.8 & 1.8 \\
\hline Arenes $\left(C_{6}-C_{10}\right)$ & 49.5 & 50.2 & 47.4 & 49.4 & 50.0 \\
\hline benzene & 7.0 & 7.3 & 6.8 & 7.3 & 6.7 \\
\hline methylbenzene & 14.7 & 14.7 & 14.0 & 14.9 & 14.6 \\
\hline ethylbenzene & 3.4 & 3.2 & 2.9 & 2.9 & 2.9 \\
\hline dimethylbenzenes & 12.0 & 12.4 & 11.6 & 11.9 & 12.2 \\
\hline
\end{tabular}

tunnel. On the other hand, the proportions of these hydrocarbons are significantly lowered by the high content of arenes in petrol (Neligan et al., 1961). The pentenes are present in about the same proportions as in petrol vapour (Löfgren et al., 1991a), whereas the butenes (notably methylpropene and 1-butene) are partly formed by combustion. The parallel samples taken on each occasion served to check sampling losses incidentally observed for 1,3-butadiene (Neligan et al., 1961) and certain $\mathrm{C}_{4}-\mathrm{C}_{6}$ alkenes. The concentration ratios between the fewer reported alkenes from the Lincoln Tunnel (Lonneman et al., 1986) were similar to those observed for the Tingstad Tunnel.

The proportion of benzene (carcinogenic) was approximately $7 \%$ and that of methylbenzene $14-15 \%$. Typical U.S. proportions are only half that size (Sheff et al., 1989) as a consequence of 
lower arene levels in the fuel (Neligan et al., 1961). Characteristic proportions of $20 \mathrm{C}_{8}-\mathrm{C}_{10}$ arenes were given in a study of the exposure of highway commuters (Löfgren et al., 1991b). The alkanes included in Table 2 are those exceeding 1\% of total non-methane hydrocarbons. For the easily volatilized butanes, higher proportions might be expected in the summer. The results indicate that such an effect is offset by the difference in butane content and volatility between Swedish summer petrol (RVP $<75 \mathrm{kPa}$ ) and winter petrol (RVP $<95 \mathrm{kPa})$. The proportion of ethyne (acetylene) as the major non-tabulated hydrocarbon was found to be 3-6\%. Hydrocarbons with more than ten carbon atoms constitute a small proportion and originate mainly from diesel vehicles (Hampton et al., 1983).

\section{DISCUSSION}

\section{Health hazards}

The high levels of benzene are disquieting with regard to the present knowledge of its toxicity (Yardley-Jones et al., 1991). Its metabolism leads to the formation of specific carcinogens. Benzene also promotes the formation of oxygen radicals more efficiently than other hydrocarbons. New evidence indicates that ethene from vehicle emissions causes $\sim 200$ cancer cases yearly in Sweden by the metabolic formation and action of its genotoxic epoxide (Törnqvist and Ehrenberg, 1990). Other alkenes, including carcinogenic 1,3-butadiene, constitute health hazards for similar reasons.

Exposure in road tunnels is hazardous to car drivers and their passengers, including vulnerable categories of people such as asthmatics, children and pregnant women. In principle, the concentrations inside a car are the same as in the surrounding air. The exposure in tunnels normally adds to an already high average exposure from car driving. The high exposure of road commuters has been demonstrated in studies from Boston (Chan et al., 1991) as well as from Göteborg (Löfgren et al., 1991b). The exposure of professional drivers should be specifically considered because of their long average exposure times.

In Sweden, the WHO limit for $\mathrm{NO}_{2}\left(400 \mu \mathrm{g} / \mathrm{m}^{3}\right)$ is presently discussed as an upper limit for vehicle pollution in road tunnels. It should be observed that the relation between the concentrations of $\mathrm{NO}_{2}$ and volatile hydrocarbons varies according to several factors (Pierson et al., 1991). It appears, therefore, that complementary limits for volatile hydrocarbons should be considered.

\section{Implications for road tunnels}

The air pollution problem is worst in long tunnels because of higher pollution levels and a longer time of exposure. Reported concentrations of hydrocarbons in a $3 \mathrm{~km}$ long road tunnel in Brussels (Vanderstraeten et al., 1991) indicate about twice as high levels as in the $0.45 \mathrm{~km}$ Tingstad Tunnel. This is so in spite of mechanical ventilation and fewer vehicles per hour. Comparable exposure levels for road and rail commuters are known from a previous study in Göteborg (Löfgren et al., 1991b). It is concluded that the exposure ratios are approximately 1:10:100 between commuter trains, commuter cars on roadways, and cars in long road tunnels.

At present, billion dollar investments in new transportation systems are being considered for the Göteborg region. A potential new E6 roadway through Göteborg would include several kilometers 
of tunnels for much of the traffic which now goes through the Tingstad Tunnel. The health hazards of air pollutants in road tunnels strengthen environmental arguments for alternative investments favouring rail transportation and electric-powered vehicles. Similar arguments should be valid for many other urban regions planning transportation systems which can meet future environmental demands.

\section{REFERENCES}

Chan C.-C., Spengler J. D., Özkaynak H. and Lefkopoulou M. (1991). Commuter exposure to VOCs in Boston, Massachusetts. J. Air Waste Manage. Assoc. 41, 1594-1600.

Dannecker W., Schröder B. and Stechmann H. (1990). Organic and inorganic substances in highway tunnel exhaust air. Sci.Total Environ.93, 293-300.

Hampton C. V., Pierson W. R., Schuetzle D. and Harvey T. M. (1983). Hydrocarbon gases emitted from vehicles on the road. 2. Determination of emission rates from diesel and spark ignition vehicles. Environ. Sci. Technol. 17, 699-708.

Lonneman W. A., Seila R. L. and Meeks S. A. (1986). Non-methane organic composition in the Lincoln Tunnel. Environ. Sci. Technol. 20, 790-796.

Löfgren L., Berglund P. M., Nordlinder R., Petersson G. and Ramnäs O. (1991a). Selective assessment of $\mathrm{C}_{2}-\mathrm{C}_{6}$ alkenes in air by adsorption sampling and gas chromatography. Int. $J$. Environ. Anal. Chem. 45, 39-44.

Löfgren L., Persson K., Strömvall A.-M. and Petersson G. (1991b). Exposure of commuters to volatile aromatic hydrocarbons of petrol exhaust. Sci. Tot. Environ. 108, 225-233.

Löfgren L. and Petersson G. (1992). Proportions of volatile hazardous hydrocarbons in vehiclepolluted urban air. Chemosphere 24, 135-140.

Neligan R. E., Mader P.P. and Chambers L.A. (1961). Exhaust composition in relation to fuel composition. JAPCA $11,178-186$.

Pierson W.R. and Gertler A. W. (1990). Comparison of the SCAQS Tunnel study with other onroad vehicle emission data. J. Air Waste Manage. Assoc. 40, 1495-1504.

Scheff P. A., Wadden R. A., Bates B. A. and Aronian P. F. (1989). Source fingerprints for receptor modeling of volatile organics. JAPCA 39 , 469-478.

Stump F. D., Tejada S., Ray W., Dropkin D., Black F., Crews W., Snow R., Siudak P., Davis C. O., Baker L. and Perry N. (1989). The influence of ambient temperature on tailpipe emissions from 1984-1987 model year light-duty gasoline motor vehicles. Atmos. Environ. 23, 307- 320.

Törnqvist M. and Ehrenberg L. (1990). Approaches to risk assessment of automotive engine exhausts. IARC Sci. Publ. 104 (Complex Mixtures and Cancer Risk), 277-287.

Vanderstraeten P. F., Wauters E. L. and Verduyn G. E. (1991). Tunnel air quality. The carbon balance as an alternative to evaluate traffic emissions. Staub-Reinhalt. Luft $\underline{51}, 83-90$.

Yardley-Jones A., Anderson D. and Parke D. V. (1991). The toxicity of benzene and its metabolism and molecular pathology in human risk assessment. Br. J. Ind. Med. 48, 437-444. 